\title{
Uncoupling the mechanisms that facilitate cell survival in hormone-deprived bovine mammary explants
}

\author{
Amelia J Brennan, Julie A Sharp, Christophe M Lefèvre and Kevin R Nicholas
}

CRC for Innovative Dairy Products, Department of Zoology, University of Melbourne, Gate 13 Royal Parade, Melbourne, Victoria 3010, Australia

(Correspondence should be addressed to A J Brennan; Email: a.brennan2@pgrad.unimelb.edu.au)

\begin{abstract}
Mammary explants can be hormonally stimulated to mimic the biochemical changes that occur during lactogenesis. Previous studies using mammary explants concluded that the addition of exogenous macromolecules were required for mammary epithelial cells to remain viable in culture. The present study examines the survival of mammary explants from the dairy cow using milk protein gene expression as a functional marker of lactation and cell viability. Mammary explants cultured from late pregnant cows mimicked lactogenesis and showed significantly elevated milk protein gene expression after 3 days of culture with lactogenic hormones. The subsequent removal of exogenous hormones from the media for 10 days resulted in the down-regulation of milk protein genes. During this time, the mammary explants remained hormone responsive, the alveolar architecture was maintained and the expression of milk protein genes was re-induced after a second challenge with lactogenic hormones. We report that a population of bovine mammary epithelial cells have an intrinsic capacity to remain viable and hormone responsive for extended periods in chemically defined media without any exogenous macromolecules. In addition, we found mammary explant viability was dependent on de novo protein and RNA synthesis. Global functional microarray analysis showed that differential expression of genes involved in energy production, immune responses, oxidative stress and apoptosis signalling might contribute to cell survival. As the decline in milk production in dairy cattle after peak lactation results in considerable economic loss, the identification of novel survival genes may be used as genetic markers for breeding programmes to improve lactational persistency in dairy cows.
\end{abstract}

Journal of Molecular Endocrinology (2008) 41, 103-116

\section{Introduction}

The production of milk during lactation is a common feature of all mammals and provides offspring with the essential nutrients required for the early stages of growth and development post partum. Some species, such as the dairy cow, have been domesticated and specifically bred to produce large quantities of milk for human consumption. Lactation in the dairy cow reaches a peak in milk yield and quality, after which milk production gradually declines (Stefanon et al. 2002). The principal cause of the decrease in milk production is the result of an imbalance between cell proliferation and cell removal (Capuco et al. 2003). Thus, the persistency of lactation is strongly influenced by the rate of cell death by apoptosis in the lactating gland (Capuco et al. 2003).

During late lactation, milking is terminated and a non-lactating period ensues, which is necessary for optimal milk production in the following lactation (Capuco \& Akers 1999). Although the cessation of milking or weaning of offspring causes involution of mammary glands in most mammals, the morphological changes that occur during the dry period in the dairy cow are less pronounced than in other species (Capuco \& Akers 1999). Much of our present knowledge of involution is based on work with the rodent, which shows the process comprises two phases: early limited apoptosis of secretory cells followed by widespread apoptosis and tissue remodelling (Stein et al. 2004). Milk accumulates locally within the alveolar lumen, and the levels of systemic lactogenic hormones fall (Green \& Streuli 2004). Phase 1 is considered a reversible process as cells undergo apoptosis at a time when the basement membrane appears largely intact. In mice, lactation can be re-established if pups are returned within 2 days of removal (Furth 1999, Green \& Streuli 2004). Mammary derived signals, specifically the accumulation of milk, are responsible for initiating the first phase of involution (Quarrie et al. 1996, Green \& Streuli 2004). The second phase commences as involution progresses $\sim 3$ days after weaning. Up-regulated activity of matrix metalloproteinases (MMPs) and serine proteases cause basement membrane disorganisation and the lobular-alveolar architecture of the gland is destroyed (Benaud et al. 1998, Furth 1999, Lee et al. 2001). The irreversible process of basement membrane degradation and removal ultimately leads

DOI: 10.1677/JME-08-0035 Online version via http://www.endocrinology-journals.org 
to tissue remodelling and commitment to involution (Furth 1999).

By contrast, although a population of bovine mammary epithelial cells undergo apoptosis initiated by milk stasis, neither sloughing of epithelial cells into the alveolar lumen nor detachment from the basement membrane occurs during the non-lactating period in dairy cows (Sordillo \& Nickerson 1988, Hurley 1989). Present management results in significant overlap of lactation and pregnancy, so animals are typically pregnant when milking is terminated. Thus, when milk stasis occurs, the mammogenic and lactogenic stimulation of pregnancy opposes stimuli for mammary involution (Capuco \& Akers 1999). However, even without the protective effect of a concurrent pregnancy, the alveolar structure is partially maintained for several weeks after the cessation of milking (Tatarczuch et al. 1997) and lactation can be reinitiated after 4 weeks or more of involution (Capuco \& Akers 1999).

There is a significant financial advantage to improve the persistence of lactation in the dairy cow, as the decline in milk yield and quality after peak lactation results in considerable economic loss for the dairy industry (Capuco et al. 2003). As the decline in milk yield after peak lactation is principally caused by an increased rate in cell death of secretory mammary epithelium by apoptosis, improved milk production in dairy cows will result from either reduced cell loss by apoptosis or increased cell survival of mammary epithelium (Capuco \& Akers 1999, Capuco et al. 2003). A mammary explant culture model provides a unique system to investigate the regulation of mammary gland function in vitro (Recklies et al. 1985). The induction of milk protein synthesis in mammary gland explants requires that the tissue is maintained in a viable state and stimulated by the appropriate complex of hormones (Topper \& Freeman 1980). Previous studies have concluded that mammary explants require the addition of either serum, a growth factor or insulin to retain viability of mammary tissue in culture (Topper \& Freeman 1980, Kulski \& Hartmann 1983, Topper et al. 1984). It has been suggested that the withdrawal of these hormones is responsible for epithelial cell death in bovine mammary gland explants (Accorsi et al. 2002). We have reported previously that mammary explants from pregnant tammar wallabies and mice could be induced to express milk protein genes but then remained viable and hormone responsive for at least 10 days in the absence of exogenous macromolecules (Brennan et al. 2008). We proposed that the mammary explant culture model uncouples the first phase of involution, as milk accumulation that normally provides involution stimuli is absent and may allow a population of cells to survive. In the present study, we found bovine mammary explants also have a population of surviving cells that remain hormone responsive, are capable of endocrine-stimulated milk protein gene expression and maintain alveolar architecture in the absence of exogenous hormones and growth factors for at least 10 days. This report investigates this unique observation to characterise the molecular events associated with bovine mammary epithelial cell survival.

\section{Materials and methods}

\section{Animals}

Mammary tissue was obtained following the slaughter of pregnant Friesian dairy cows at late pregnancy (8 months) in a commercial abattoir. The cows were maintained in open pastures throughout Gippsland, Victoria, Australia. Animals were killed by electrical stunning and exsanguination. Samples $(\sim 30 \mathrm{~g})$ of secretory alveolar mammary tissue were obtained from the middle of the upper one-third of the gland of a rear quarter. Some tissues were either snap frozen in dry ice for subsequent RNA extraction or preserved in $4 \%$ paraformaldehyde solution for histological analysis. In addition, $\sim 1.5 \mathrm{~cm}$ thick $\times 10 \mathrm{~cm}$ long samples of alveolar tissue were transferred to Medium 199 for explant culture.

\section{Tissue culture}

Mammary gland explants were prepared and cultured in Medium 199 with Earle's salts (Gibco BRL Life Technologies), as described previously (Nicholas \& Tyndale-Biscoe 1985). Briefly, the explants were incubated at $37^{\circ} \mathrm{C}\left(5 \% \mathrm{CO}_{2}\right)$ in Medium 199 without the addition of growth factors or hormones $(\mathrm{NH})$ or with the combination of bovine insulin ( $\mathrm{I} ; 1 \mu \mathrm{g} / \mathrm{ml}$, Sigma \#I-5500), hydrocortisone (F; $50 \mathrm{ng} / \mathrm{ml}$, Sigma \#H-4001) and ovine prolactin $(\mathrm{P} ; 1 \mu \mathrm{g} / \mathrm{ml}$, National Hormone and Pituitary Program USA NIDDK-oPRL-21). Mammary explants were collected and frozen at $-80{ }^{\circ} \mathrm{C}$ for northern analysis. For histological analysis, the mammary explants were preserved in $4 \%$ paraformaldehyde solution.

\section{Light microscopy}

Tissue and explants were fixed in $4 \%$ paraformaldehyde. Samples were processed (Citadel; Shandon Scientific Ltd, Cheshire, England) and embedded in paraffin using routine procedures. Paraffin-embedded sections of $8 \mu \mathrm{m}$ thickness were cut, mounted on 3-aminopropyltriethoxysilane-coated slides and submerged in histolene to remove the paraffin. After rehydration, transverse sections were stained with haematoxylin and eosin (Kiernan 2000). Adjacent paraffin sections were 
immunolabelled for in situ apoptosis using the terminal deoxyribonucleotidyl transferase nick end labelling (TUNEL) assay. Finally, the sections were coverslipped, examined using light microscopy and photographed with a Coolscope digital (Nikon, Melville, NY, USA) camera for cytoarchitectural integrity.

\section{Immunohistochemistry: in situ end labelling of frag- mented DNA}

Paraffin-embedded sections of $8 \mu \mathrm{m}$ thickness were cut, mounted on 3-aminopropyl-triethoxysilane-coated slides and submerged in histolene to remove the paraffin. For detection of DNA fragmentation as a biochemical marker of apoptosis, transverse sections were subjected to TUNEL using an ApopTag peroxidase assay kit (Chemicon \#S7100, North Ryde, NSW, Australia). Negative control sections processed without TdT enzyme were used to ensure that positive staining was not due to nonspecific incorporation of nucleotides. The sections were counterstained with $0.5 \%$ methyl green, coverslipped, examined and photographed using a Coolscope digital camera (Nikon) for light microscopy. ApopTag positive cells were brown and considered apoptotic cells. ApopTag negative cells were green and considered live cells.

\section{Northern blot analyses}

Total RNA was isolated from the tissue using a Qiagen RNA extraction kit (Qiagen \#75144) following the manufacturer's instructions. For analysis, $10 \mu \mathrm{g}$ total RNA was electrophoresed in 3-(N-morpholino) propanesulfonic acid (MOPS) $1 \%$ agarose gel at $100 \mathrm{~V} / \mathrm{cm}$ using $10 \%$ MOPS buffer, transferred to Zeta-probe GT membranes and pre-hybridised for $4 \mathrm{~h}$ at $42^{\circ} \mathrm{C}$ in $30 \%$ formamide buffer. The membranes were hybridised at $42{ }^{\circ} \mathrm{C}$ with b-lactoglobulin (BLG) and $\beta$-casein cDNA labelled with $\left[\alpha_{-}^{-32} \mathrm{P}\right] \mathrm{dCTP}\left(\left[\alpha^{-32} \mathrm{P}\right] \mathrm{dCTP} 10 \mu \mathrm{Ci} / \mathrm{ml}\right.$, PerkinElmer, Melbourne, VIC, Australia) prepared with DECAprime II random priming DNA labelling kit (Ambion \#1455, Scoresby, VIC, Australia) following the manufacturer's instructions. The membranes were washed once at room temperature with $2 \%$ SSC and $1 \%$ SDS, twice at room temperature with $1 \%$ SSC and $0 \cdot 1 \%$ SDS and twice at $42{ }^{\circ} \mathrm{C}$ in $0 \cdot 1 \%$ SDS and $0 \cdot 1 \%$ SSC. The ${ }^{32} \mathrm{P}$-labelled cDNA was detected by the use of a phosphoimage cassette at room temperature for 24-48 h (BioRad, Molecular Dynamics, Gladesville, NSW, Australia).

\section{RNA synthesis: $\left[{ }^{3} \mathrm{H}\right]$ uridine incorporation}

The rate of RNA synthesis was determined (Falconer et al. 1978) after incubating explants with uridine $\left[5,6-{ }^{3} \mathrm{H}\right](37 \mathrm{Ci} / \mathrm{mmol})$ (ICN \#2404.6) $1.0 \mu \mathrm{Ci} / \mathrm{ml}$ for $4 \mathrm{~h}$. Radioactivity was determined in a liquid scintilation spectrophotometer (PerkinElmer, Tri-CARB 2100T).

\section{Protein synthesis: $\left[{ }^{3} \mathrm{H}\right]$ leucine incorporation}

Protein synthesis was measured in explant cultures following the addition of L-leucine $\left[4,5-{ }^{3} \mathrm{H}\right]$ $(51 \mathrm{Ci} / \mathrm{mmol}$ ) (ICN \#200360) to culture media at $1.0 \mu \mathrm{Ci} / \mathrm{ml}$ for a 4 - $\mathrm{h}$ incubation. The explants were removed, dried, weighed and stored at $-80{ }^{\circ} \mathrm{C}$ until analysis. Frozen tissue was added to $0 \cdot 6 \mathrm{ml}$ Milli-Q water and immediately homogenised. Proteins were precipitated with $600 \mu \mathrm{l}$ cold $20 \%$ trichloroacetic acid (TCA) and the solution placed on ice for $30 \mathrm{~min}$. After centrifugation at $9300 \mathrm{~g}$ for $5 \mathrm{~min}$, the supernatant was discarded and the pellet washed twice with $1 \mathrm{ml}$ of $5 \%$ TCA. To ensure any excess unbound $\left[{ }^{3} \mathrm{H}\right]$ leucine was removed, the pellet was disturbed by vigorous vortexing. The final pellet was dissolved in $100 \mathrm{mM}$ $\mathrm{NaOH}$ and incubated overnight. Once the pellet was dissolved, $400 \mu \mathrm{l}$ was added to $5 \mathrm{ml}$ Ultima Gold scintillation fluid (PerkinElmer \#6013329) and radioactivity determined in a liquid scintillation spectrophotometer (PerkinElmer, Tri-CARB 2100T).

\section{Inhibition of RNA and protein synthesis}

Total RNA synthesis was inhibited (Goldstein et al. 2005) by incubating explants with actinomycin-D $(1 \mu \mathrm{g} / \mathrm{ml})$, and total protein synthesis was inhibited (Rillema et al. 2000) by incubating explants with cyclohexamide $(5 \mu \mathrm{g} / \mathrm{ml})$, in media containing $\mathrm{NH}$ for 5 days. Before media containing insulin, cortisol and prolactin (IFP) was added, the wells were washed twice with $1 \times$ PBS to prevent carry-over of inhibitors. Total RNA was isolated from the tissue using a Qiagen RNA extraction kit (Qiagen \#75144) and northern blot analysis was used to investigate milk protein gene expression. Significant differences between the level of RNA synthesis and protein synthesis, with and without actinomycin-D and cyclohexamide treatment respectively, were determined by two-way ANOVAs followed by Tukey's multiple comparison tests. In all analyses, $P<0 \cdot 01$ were considered statistically significant.

\section{Affymetrix microarray}

A bovine genome array (Affymetrix Genechip, Australian Genome Research Facility, Melbourne, VIC, Australia) was used to study the gene expression of over 23000 bovine transcripts. Total RNA of tissue from midpregnant animals prior to culture, explants cultured for 5 days without hormones, and the explants cultured for 5 days without hormones with subsequent introduction of IFP for 3 days, was isolated using a Qiagen lipid RNA extraction kit (Qiagen \#74804). Each experiment was repeated for two biological replicates. Microarrays were hybridised and scanned by the Australian Genome Research Facility, Melbourne, VIC, Australia, and 
normalised using the log scale robust multi-array analysis (Irizarry et al. 2003). Datasets were analysed for function using the Ingenuity Pathways Analysis software (Ingenuity ${ }^{\circledR}$ Systems, http://www.ingenuity.com).

\section{Results}

\section{Induction of milk protein gene expression in cow mammary explants}

Milk protein gene expression was analysed in cow mammary explants exposed to various hormone treatments (Fig. 1). Mammary tissue from pregnant cows showed a low level of $\alpha \mathrm{S} 1$-casein and BLG gene expression, which was significantly elevated in mammary explants after 3 days of culture in medium 199 containing insulin, cortisol and prolactin $\left(\mathrm{IFP}_{3}\right)$. The $\alpha \mathrm{S} 1$-casein and BLG transcripts were not detected in mammary explants after 5 or 10 days of culture in the absence of exogenous growth factors or hormones $\left(\mathrm{NH}_{5}, \mathrm{NH}_{10}\right)$. Subsequent addition of IFP to media for 3 days after culture in $\mathrm{NH}$ for $5\left(\mathrm{NH}_{5} \rightarrow \mathrm{IFP}_{3}\right.$ (six animals)) or 10 days $\left(\mathrm{NH}_{10} \rightarrow \mathrm{IFP}_{3}\right.$ (six animals)) resulted in significantly increased levels of $\alpha \mathrm{S} 1$-casein and BLG transcripts. To investigate whether an initial incubation in IFP affects subsequent explant survival, mammary explants were first cultured with IFP for 3 days to induce milk protein gene expression and mimic lactogenesis. Removal of exogenous IFP from the media for either 5 or 10 days resulted in the downregulation of $\alpha \mathrm{S} 1$-casein and $\mathrm{BLG}$ gene expression in explants $\left(\mathrm{IFP}_{3} \rightarrow \mathrm{NH}_{5}, \mathrm{IFP}_{3} \rightarrow \mathrm{NH}_{10}\right)$. The reintroduction of IFP to media for 3 days after culture for either 5 $\left(\mathrm{IFP}_{3} \rightarrow \mathrm{NH}_{5} \rightarrow \mathrm{IFP}_{3}\right)$ or 10 days $\left(\mathrm{IFP}_{3} \rightarrow \mathrm{NH}_{10} \rightarrow \mathrm{IFP}_{3}\right)$, in the absence of hormones in cultures from six out of eight animals and four out of eight animals respectively, resulted in the stimulation of as1-casein and BLG gene expression. The lack of a response in some of the

(a)

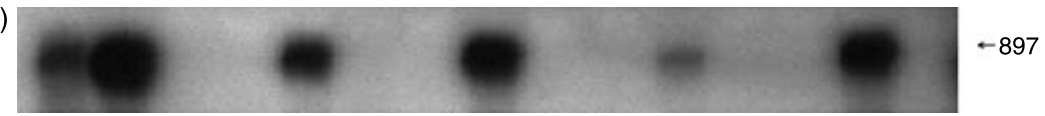

(b)

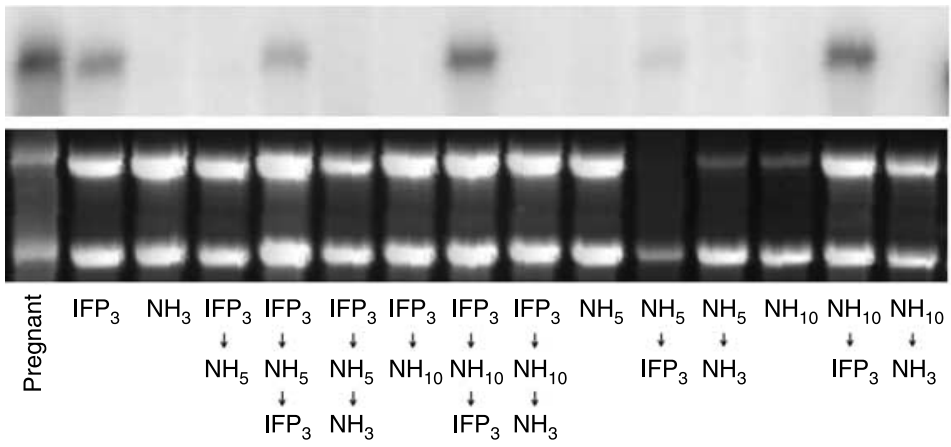

Figure 1 Expression analysis of cow mammary explants from mid-pregnant animals. Upper panel, $\alpha$-S1 casein gene; middle panel, $\beta$-lactoglobulin gene. Total RNA (10 $\mu \mathrm{g})$ was assayed by northern analysis using (a) $\alpha$-S1 casein- and (b) $\beta$-lactoglobulin-labelled probes. Lower panel shows equal loadings as determined by visualisation of $28 \mathrm{~S}$ and $18 \mathrm{~S}$ RNA bands. Treatments included: pregnant, mammary explants from pregnant cows; $\mathrm{IFP}_{3}$, mammary explants from pregnant cows were cultured in M199 containing insulin $(\mathrm{l} ; 1 \mu \mathrm{g} / \mathrm{ml})$, cortisol $(\mathrm{F} ; 50 \mathrm{ng} / \mathrm{ml})$ and prolactin $(\mathrm{P} ; 1 \mu \mathrm{g} / \mathrm{ml})$ for 3 days; $\mathrm{NH}_{3}$, mammary explants from pregnant cows were cultured in M199 containing no hormone or growth factors for 3 days; IFP $3 \rightarrow \mathrm{NH}_{5}$ and IFP $\rightarrow \mathrm{NH}_{10}$, mammary explants from pregnant cows were cultured in M199 containing insulin, cortisol and prolactin for 3 days, which were removed and explants were cultured for a further 5 or 10 days with no hormone or growth factors in the media; IFP $\rightarrow \mathrm{NH}_{5} \rightarrow \mathrm{IFP}_{3}$ and IFP $3 \rightarrow \mathrm{NH}_{10} \rightarrow \mathrm{IFP}_{3}$, mammary explants from pregnant cows were cultured in M199 containing insulin, cortisol and prolactin for 3 days, and then removed, explants were further cultured for 5 or 10 days with no hormones or growth factors in the media, after which insulin, cortisol and prolactin were reintroduced for 3 days; IFP $\rightarrow \mathrm{NH}_{5} \rightarrow \mathrm{NH}_{3}$ and IFP $\rightarrow \mathrm{NH}_{10} \rightarrow \mathrm{NH}_{3}$, mammary explants from pregnant cows were cultured in M199 containing insulin, cortisol and prolactin for 3 days, which were removed and explants were cultured for 8 or 13 days in total with no hormone or growth factors in the media; $\mathrm{NH}_{5}$ and $\mathrm{NH}_{10}$, mammary explants from pregnant cows were cultured in M199 containing no hormone or growth factors for 5 or 10 days; $\mathrm{NH}_{5} \rightarrow I F P_{3}$ and $\mathrm{NH}_{10}$ $\rightarrow \mathrm{IFP}_{3}$, mammary explants from pregnant cows were cultured in M199 containing no hormone or growth factors for 5 or 10 days followed by introduction of insulin, cortisol and prolactin for 3 days; $\mathrm{NH}_{5} \rightarrow \mathrm{NH}_{3}$ and $\mathrm{NH}_{10} \rightarrow \mathrm{NH}_{3}$, mammary explants from pregnant cows were cultured in M199 containing no hormone or growth factors for a total of 8 or 13 days. Arrows indicate transcript size in nucleotides and RNA ribosomal bands. 
mammary tissues tested was most likely because the cows were too near parturition for prolactin-dependent induction of milk protein gene expression in explants, as described by Sheehy et al. (2004).

\section{Morphological evaluation of mammary tissue and mammary explants from the cow}

Cellular architecture of bovine mammary tissue and mammary explants showing a hormone induced increase in $\alpha$ S1-casein and BLG transcripts was examined (Fig. 2). Histological examination of the mammary tissue from a pregnant cow shows the organisation of immature alveoli in preparation for the onset of lactation at parturition (Fig. $2 \mathrm{a}$ and $\mathrm{f}$ ). The slides prepared from the mammary tissue of a pregnant cow after culture for 3 days in IFP media $\left(\mathrm{IFP}_{3}\right)$, after culture for 3 days in IFP media followed by the removal of hormones for a subsequent 5 or 10 days $\left(\mathrm{IFP}_{3} \rightarrow \mathrm{NH}_{5}, \mathrm{IFP}_{3} \rightarrow \mathrm{NH}_{10}\right)$ and after culture for 3 days in IFP media followed by the removal of hormones for 5 or 10 days and the subsequent reintroduction of IFP for a further 3 days $\left(\mathrm{IFP}_{3} \rightarrow\right.$ $\left.\mathrm{NH}_{5} \rightarrow \mathrm{IFP}_{3}, \mathrm{IFP}_{3} \rightarrow \mathrm{NH}_{10} \rightarrow \mathrm{IFP}_{3}\right)$ indicate that the cellular architecture of the tissue was well conserved throughout the entire culture period regardless of hormone conditions. The gland is still predominantly composed of stroma; however, the alveoli have expanded and epithelial cells are flattened, which is consistent with a lactating phenotype (Fig. 2k, p, b-e and g-j). The slides prepared from the mammary tissue of a pregnant cow after culture in $\mathrm{NH}$ for 5 or 10 days $\left(\mathrm{NH}_{5}, \mathrm{NH}_{10}\right)$ show that alveoli are smaller and flattened with a compressed lumen. After the introduction of IFP media for 3 days, however $\left(\mathrm{NH}_{5} \rightarrow \mathrm{IFP}_{3}, \mathrm{NH}_{10} \rightarrow \mathrm{IFP}_{3}\right)$, the morphology of

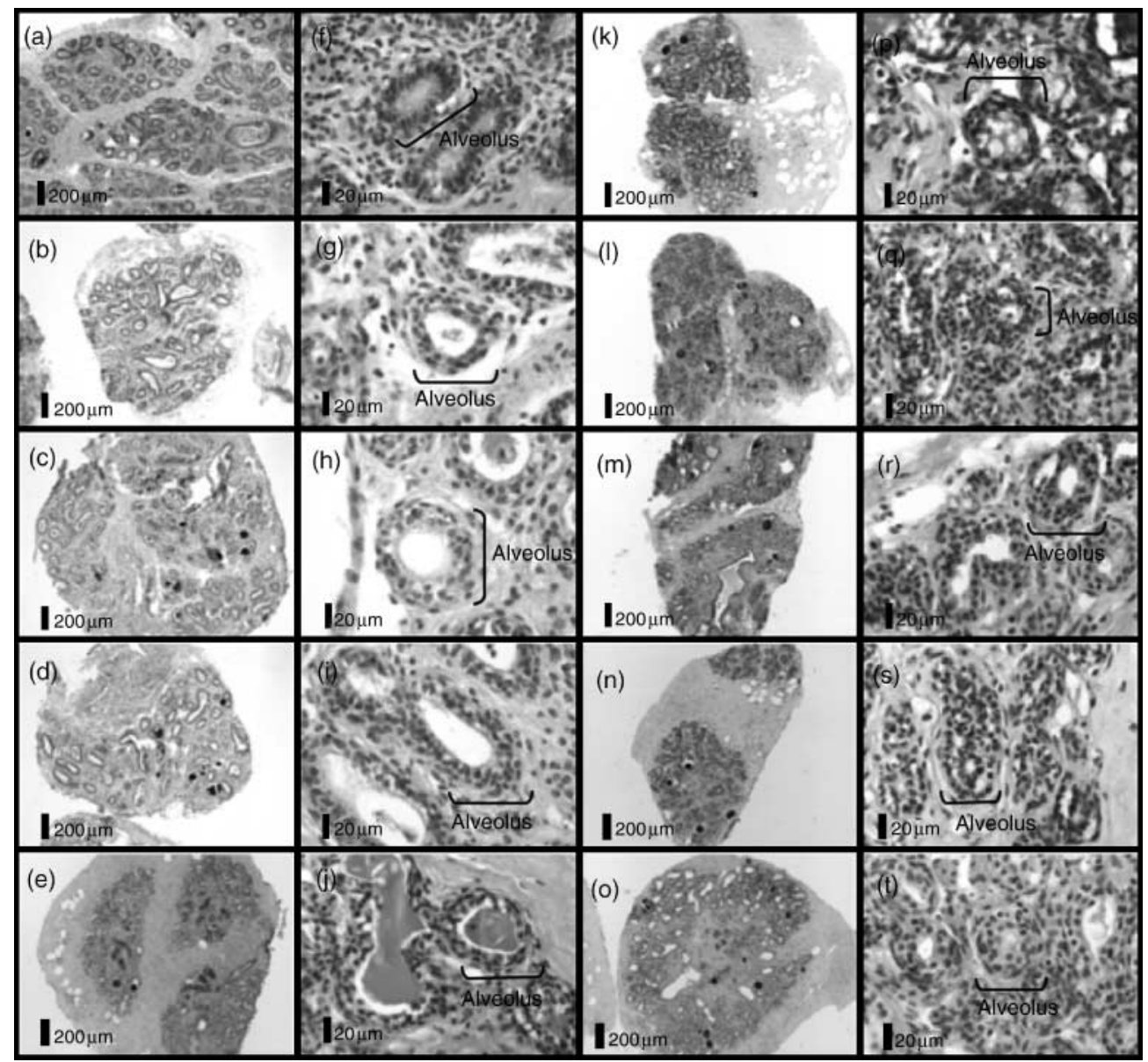

Figure 2 Morphology of mid-pregnant cow mammary tissue and explants. Haematoxylin- and eosin-stained sections of mid-pregnant cow mammary tissue and explants. (a and f) Mammary explant from a midpregnant cow, (b and g) mammary explant from a pregnant cow cultured in IFP (d and i) IFP $\rightarrow \mathrm{NH}_{5} \rightarrow \mathrm{IFP}_{3}$, (e and j) IFP $\rightarrow \mathrm{NH}_{10}$, (k and p) IFP $\rightarrow \mathrm{NH}_{10} \rightarrow \mathrm{IFP}_{3}$, (i and q) $\mathrm{NH}_{5}$, (m and $\mathrm{r}$ ) $\mathrm{NH}_{5} \rightarrow \mathrm{IFP}_{3}$, ( $\mathrm{n}$ and $\mathrm{s}$ ) $\mathrm{NH}_{10}$, (o and $\mathrm{t}$ ) $\mathrm{NH}_{10} \rightarrow \mathrm{IFP}_{3}$. Abbreviations of treatments are described in the legend of Fig. 1. Examples of alveoli are indicated. 
the alveoli show a distended lumen and flattened epithelia typical of a lactating phenotype (Fig. 21-o and q-s).

\section{Apoptosis evaluation of mammary tissue and mam- mary explants from the cow}

Induction of DNA fragmentation as a biochemical feature of apoptosis was examined by the use of an ApopTag assay in cow mammary tissue and explants. All control slides showed non-specific background stromal staining not associated with apoptosis. The mammary tissue from a pregnant cow showed the absence of apoptotic cells (Fig. 3a), while mammary explants cultured for 3 days in $\mathrm{IFP}_{3}$ showed the presence of many apoptotic cells (Fig. 3b). However, there is also a non-apoptotic population of mammary epithelial cells that are maintained within the alveolar architecture in the explants.

\section{Inhibition of total RNA and protein synthesis}

In order to determine whether RNA or protein synthesis is required for explants to remain viable and hormone responsive when cultured in the absence of hormones or growth factors, total RNA and protein synthesis were inhibited with the addition of actinomycin-D and cyclohexamide respectively (Fig. 4). The synthesis of protein and total RNA in mammary explants from pregnant cows were analysed by the incorporation of ${ }^{3} \mathrm{H}$-leucine and ${ }^{3} \mathrm{H}$-uridine respectively, which showed a progressive increase after 5 days of culture in the absence of hormones $\left(\mathrm{NH}_{5}\right.$; Fig. $4 \mathrm{a}$ and $\left.\mathrm{b}\right)$. A two-way ANOVA of the synthesis of protein and total RNA in cyclohexamide and actinomycin-D-treated and untreated explants over time showed a significant effect (protein, Table 1; total RNA, Table 2). The subsequent introduction of IFP to media for 1 and 3 days showed that the inhibition of protein and total RNA synthesis prevented milk protein gene expression $\left(\mathrm{NH}_{5} \rightarrow \mathrm{IFP}_{3}\right.$; Fig. 5a and b).

\section{Analysis of gene expression in cow mammary explants and involuting mammary glands}

In order to characterise gene expression profiles from mammary tissue and explants, bovine Affymetrix microarrays were used to compare transcript profiles. Genes were considered differentially expressed if there was a twofold or more increase or decrease in intensity between treatments. Northern blot (Fig. 1) validated microarray analysis, as milk protein gene expression was up-regulated in mammary tissue from mid-pregnant animals prior to culture, down-regulated in mammary explants cultured for 5 days in $\mathrm{NH}\left(\mathrm{NH}_{5}\right)$ and up-regulated a second time in mammary explants cultured for 5 days without hormones with subsequent introduction of IFP for 3 days $\left(\mathrm{NH}_{5} \rightarrow \mathrm{IFP}_{3} ; \mathrm{Fig}\right.$. 6$)$. The differences between treatments was found to be statistically significant by a two-way ANOVA with intensity as the dependent variable and treatment and gene as factors (ANOVA $F_{2,2}=29 \cdot 9, P<0 \cdot 05$ ).

Microarray analysis of mammary tissue from midpregnant animals prior to culture, and the explants cultured for 5 days in $\mathrm{NH}\left(\mathrm{NH}_{5} ; n=2\right)$ showed 1119 genes up-regulated (uniquely annotated $=412$ ) and 1430 genes down-regulated (uniquely annotated $=$ 223). Tissue from mid-pregnant animals and explants cultured for 5 days without hormones with subsequent introduction of IFP for 3 days were compared $\left(\mathrm{NH}_{5} \rightarrow\right.$ $\left.\mathrm{IFP}_{3} ; n=2\right)$ and showed 1144 genes up-regulated (uniquely annotated =286) and 1449 genes downregulated (uniquely annotated $=80$ ). Differentially expressed genes in the mammary tissue of involuting

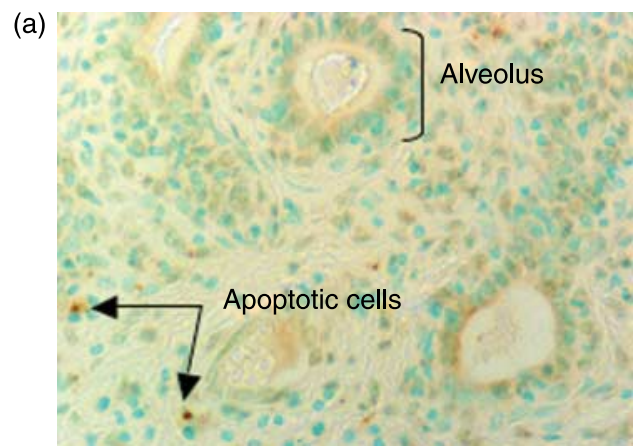

(b)

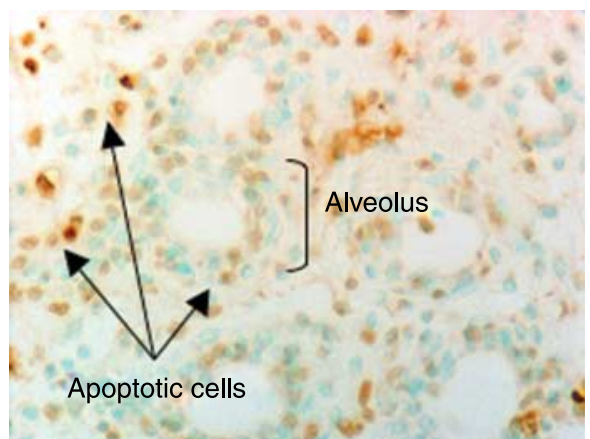

Figure 3 Apoptotic cells in cow mammary tissue and explant sections. ApopTag-stained apoptotic cells were visualised by the use of a brown immunogen within the mammary tissue at $40 \times$ magnification. The sections were counterstained with methyl green to show the presence of non-apoptotic cells. (a) Mammary explants from a pregnant cow, (b) Mammary explants from pregnant cows cultured in M199 containing insulin, cortisol and prolactin for 3 days $\left(\mathrm{IFP}_{3}\right)$. Tissues from both a pregnant cow and explant cultured in $\mathrm{IFP}_{3}$ show adequate maintenance of epithelial and stromal compartments, although there are more apoptotic cells in the explanted tissue. Examples of alveoli and apoptotic cells are indicated. 

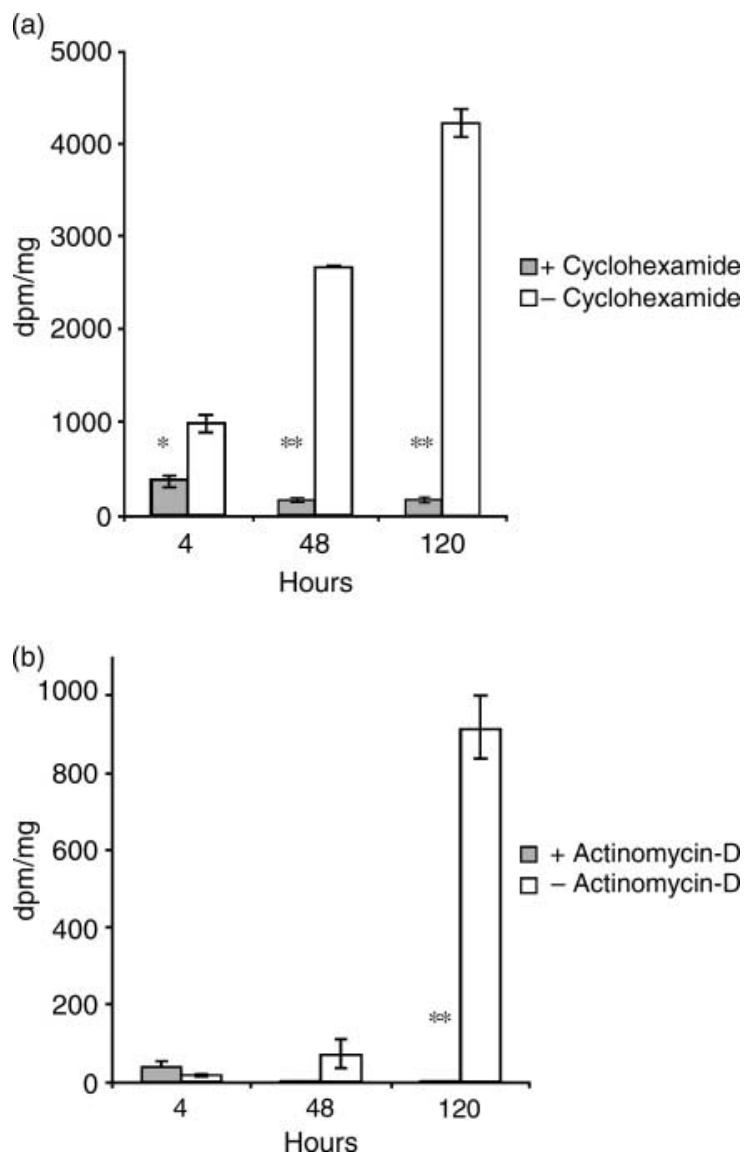

Figure 4 Hormone-independent synthesis of protein and total RNA in cow mammary explants. Mammary explants from midpregnant cows were cultured in M199 containing no hormones or growth factors in the media. (a) The rate of protein synthesis in explants was determined by exposure to $\left[{ }^{3} \mathrm{H}\right]$ uridine $(1 \mu \mathrm{Ci} / \mathrm{ml})$ for the final $4 \mathrm{~h}$ of culture. Protein synthesis was inhibited by the addition of cyclohexamide. Each value represents mean \pm S.E.M. $(n=2)$. (b) The rate of RNA synthesis in explants was determined by exposure to $\left[{ }^{3} \mathrm{H}\right]$ leucine $(1 \mu \mathrm{Ci} / \mathrm{ml})$ for the final $4 \mathrm{~h}$ of culture. RNA synthesis was inhibited by the addition of actinomycin- $D$. Each value represents mean \pm S.E.M. $(n=2)$. A two-way ANOVA showed (a) protein and (b) total RNA synthesis increased significantly over 5 days of culture $(P<0.001)$. Post hoc Tukey's pairwise comparison indicated significant differences between the rate of (a) protein synthesis and (b) total RNA synthesis, between (a) cyclohexamide and (b) actinomycin-D-treated mammary explants, and control mammary explants. ${ }^{\star} P<0.01$, ${ }^{\star \star} P<0.001$.

cows $(n=4)$, compared with the mammary tissue of pregnant cows $(n=4)$, were obtained from the Cooperative Research Centre (CRC) for Innovative Dairy Products, University of Sydney, and showed a total of 826 (uniquely annotated $=63$ ) up-regulated genes and 761 (uniquely annotated $=133$ ) down-regulated genes. These genes were compared with the differentially expressed genes from mammary explants (Fig. 7).

Datasets were integrated and analysed for function to investigate gene expression profiles in mammary explants using the Ingenuity Pathways Analysis software (Ingenuity
Table 1 Two-way ANOVA of the temporal levels of protein synthesis in bovine mammary explants in the presence or absence of cyclohexamide

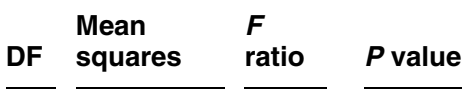

\begin{tabular}{|c|c|c|c|c|}
\hline urce & & & & \\
\hline Hours & 2 & 2274632 & 204 & $0.000^{*}$ \\
\hline Cyclohexamide treatment & 1 & 17167027 & 1541 & $0.000^{*}$ \\
\hline $\begin{array}{l}\text { Hours } \times \text { cyclohexamide } \\
\text { treatment }\end{array}$ & 2 & 3006062 & 270 & $0.000^{*}$ \\
\hline
\end{tabular}

A high overall significant difference between treatments and time was observed ( $\left.{ }^{\star} P<0 \cdot 001\right)$.

Systems, http://www.ingenuity.com; Fig. 8). The functional analysis identified the biological functions that were most significant to the dataset. Only genes from the datasets that were associated with biological functions in the Ingenuity Pathways Knowledge Base were considered for the analysis. Fischer's exact test was used to calculate a $P$ value determining the probability that each biological function assigned to that dataset was due to chance alone. Several distinct biological functions were affected in cultured explants, which included perturbation of cellular processes, cell death, energy production, immune response, protein degradation and synthesis. Comparison with involuting cow mammary glands showed that affected biological functions were more pronounced in cultured mammary explants. Pathways where a significant number of genes showed altered expression in cultured mammary tissue compared with control samples involved energy production (oxidative phosphorylation and glycolysis/gluconeogenesis), immune responses (leukocyte extravasation signalling, interleukin (IL)-10 signalling, IL-6 signalling and chemokine signalling), NF-E2 related factor 2 (NRF2)-mediated oxidative stress and apoptosis signalling (Fig. 9a and b).

A number of genes for antioxidant proteins and metabolising enzymes associated with the NRF2mediated oxidative stress pathway were up-regulated in mammary explants cultured in the absence of hormones (Fig. 10). In particular, seven of those

Table 2 Two-way ANOVA of the temporal levels of total RNA synthesis in bovine mammary explants in the presence or absence of actinomycin-D

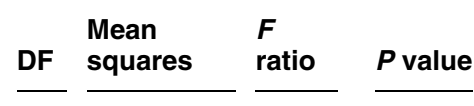

\section{Source}

Hours

241322

Actinomycin-D treatment $1 \quad 307138$ treatment

A high overall significant difference between treatments and time was observed ( $\left.{ }^{\star} P<0 \cdot 001\right)$ 
(a)
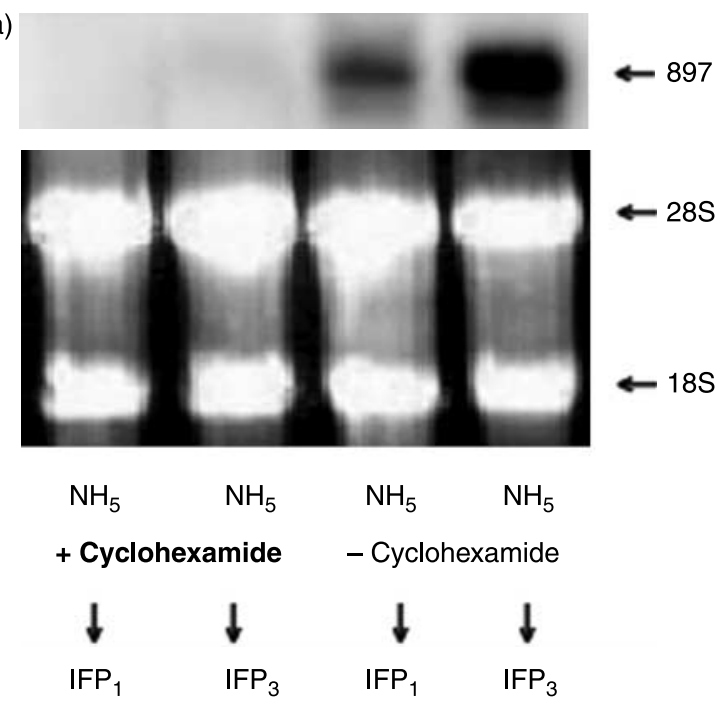

- Cyclohexamide - Cyclohexamide

(b)
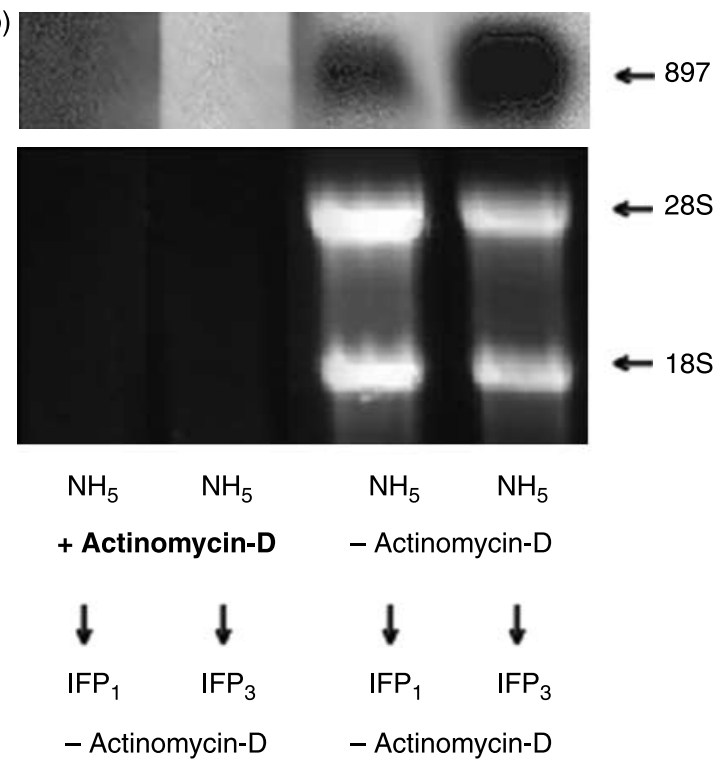

Figure $5 \alpha$-Casein gene expression in cyclohexamide- and actinomycin-D-treated explants. Mammary explants from midpregnant cows were cultured in M199 containing no hormones or growth factors in the media. (a) Protein synthesis was inhibited for 5 days by the addition of cyclohexamide (indicated by bold text). Cyclohexamide was then removed and the culture media changed to contain IFP for 3 days. $\alpha$-Casein gene expression was not up-regulated after the cyclohexamide treatment (lanes 1 and 2). Control explants (lanes 3 and 4) show that when protein synthesis is not suppressed, $\alpha$-casein gene expression can be up-regulated after culture in no hormone for 5 days. (b) Total RNA synthesis was inhibited for 5 days by the addition of actinomycin-D (indicated by bold text). Actinomycin-D was then removed and the culture media changed to contain IFP for 3 days (lanes 1 and 2). RNA was completely degraded and $\alpha$-casein gene expression was not up-regulated after the actinomycin-D treatment. Control explants (lanes 3 and 4) show that when total RNA synthesis is not suppressed by actinomycin-D $\alpha$-casein gene expression can be up-regulated after culture in no hormone for 5 days. genes including; ferritin heavy polypeptide 1, glutathione S-transferase pi (GSTP1), NADPH dehydrogenase quinone 1 , heme oxygenase 1 (HMOX1), superoxide dismutase 2 (SOD2) peroxiredoxin 1 (PRDX1) and thioredoxin (TXN) have cytoprotective properties. In addition, we identified a total of 21 genes encoding proteins linked to involution that showed altered expression in cultured mammary tissue (Fig. 9c). Nine of those genes are considered to be primarily involved in the first apoptotic and death receptor phase of involution (apoptotic $=9$, antiapoptotic $=2$ ), and 12 are involved in the second remodelling phase of involution (MMPs and tissue inhibitors of MMPs (TIMPs) $=10$, serine proteases $=2$ ). Hormones appear to provide some protection against apoptosis, as explants cultured without hormones for 5 days with the subsequent addition of IFP show up-regulation of the anti-apoptotic B-cell lymphoma protein 2 (BCL2) gene, and no change in either apoptotic related RAS viral r-ras oncogene homologue, tumour necrosis factor receptor superfamily member $1 \mathrm{~A}$ or serine protease expression.

\section{Discussion}

Mammary explants from pregnant dairy cows have the capacity to maintain a population of mammary epithelial cells in a hormone-responsive state without exposure to exogenous macromolecules during culture. This agrees with our previous study (Brennan et al. 2008) that showed tammar wallaby and mouse mammary explants also maintain a surviving population of mammary epithelial cells in the absence of any growth factors and hormones. We show for the first time in the dairy cow a population of surviving cells that remain hormone responsive, are capable of milk protein gene expression, and maintain alveolar architecture in the absence of exogenous hormones and growth factors for at least 10 days.

Microarray analysis showed that affected biological functions were more pronounced in cow mammary explants in comparison with involuting cow mammary glands. Furthermore, involution- and apoptosis-associated genes that were differentially expressed in cow mammary explants were not differentially expressed in the involuting cow mammary tissue examined in this study. Rather, microarray analysis of cow mammary gland explants showed that involution-associated genes observed predominantly in the rodent were up-regulated. This is most likely because the changes that occur during involution in the dairy animal are less pronounced than that in other species (Capuco \& Akers 1999), and is consistent with previous studies that demonstrate the withdrawal of hormones and growth factors triggers a programme of epithelial cell death in cow mammary explants within $48 \mathrm{~h}$ (Accorsi et al. 2002). 


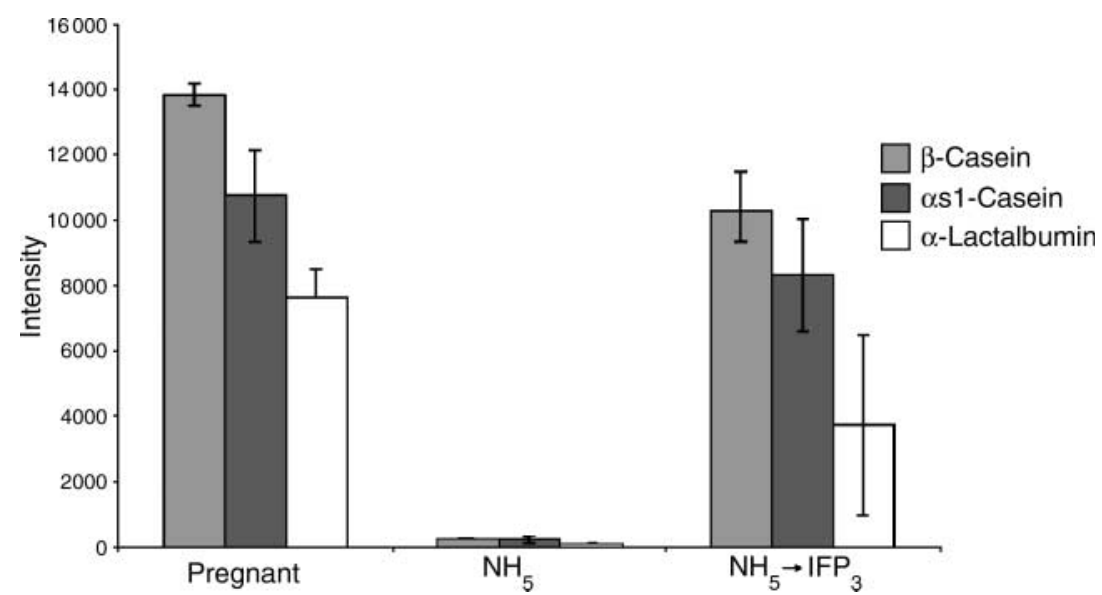

Figure 6 Microarray analysis of milk protein gene expression in cow mammary explants. cDNA probes were hybridised to bovine Affymetrix microarray chips generated from RNA from pregnant cow mammary glands $(n=2)$, explanted mammary tissue from pregnant cows cultured without hormones for 5 days $(n=2)$ and explanted mammary tissue from pregnant cows cultured without hormones for 5 days with the subsequent addition of hormones for 3 days $(n=2)$. $\beta$-casein, $\alpha$ S1-casein and $\alpha$-lactalbumin gene expression increased significantly in explanted mammary tissue from pregnant cows cultured without hormones for 5 days compared with explanted mammary tissue from pregnant cows cultured without hormones for 5 days with the subsequent addition of hormones for 3 days but not at the level in pregnant cow mammary glands. The differences between treatments was found to be statistically significant by a two-way ANOVA with intensity as the dependent variable, and treatment and gene as factors $(P<0 \cdot 05)$.

In particular, the genes that promote apoptosis, the genes that degrade extracellular matrix proteins and the pathways that cause an immune response were affected. When cultured in the absence of hormones, apoptotic genes such as Bax were up-regulated and antiapoptotic genes such as x-linked inhibitor of apoptosis (xIAP) were down-regulated. Immunohistochemical analysis shows that cow explants cultured immediately in lactogenic hormones have many more apoptotic cells in comparison with mammary tissue from a pregnant animal. It appears that most of the apoptosis that occurs in mammary explants is due to the impact of the culture procedures (Brennan et al. 2008), although lactogenic hormones potentially provide some protection against cell death through increased expression of the BCL2 gene (Green \& Streuli 2004).

The culture of cow mammary explants in the absence of hormones also causes significant up-regulation of extracellular matrix remodelling genes (MMPs and serine proteinases) and inhibitors (TIMPs). Similarly in vivo, proteinases increase in the second phase of involution in the cow, which coincides with a concomitant expression of their inhibitors (Rabot et al. 2007). Interestingly, although a population of bovine mammary epithelial cells undergo apoptosis initiated by milk stasis, neither sloughing of epithelial cells into the alveolar lumen nor detachment from the basement membrane occurs during the non-lactating period in the dairy cow (Sordillo \& Nickerson 1988, Hurley

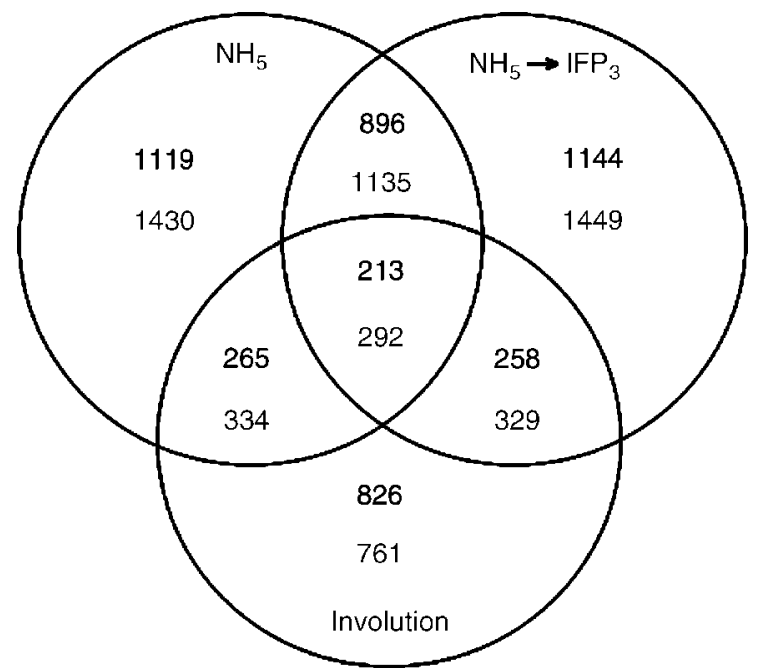

Figure 7 Comparison of cow mammary explant gene expression with involution. cDNA probes were hybridised to bovine Affymetrix microarray chips generated from RNA from pregnant cow mammary glands $(n=2)$, explanted mammary tissue from pregnant cows cultured without hormones for 5 days $(n=2)$, explanted mammary tissue from pregnant cows cultured without hormones for 5 days with the subsequent addition of hormones for 3 days $(n=2)$ and involution $(n=4)$. The Venn diagram represents the number of genes up- (bold) or down-regulated greater than fivefold in the mammary gland of the involuting cow, in mammary explants from pregnant cows cultured for 5 days in the absence of hormones and in mammary explants from pregnant cows cultured for 5 days in the absence of hormones with the subsequent addition of hormones for 3 days, as determined by Affymetrix analysis. 
Cellular growth and proliferation

Cell death

Cell signalling

Immune response

Cell-to-cell signalling and interaction

Post-translational modification

Cellular compromise

Cell cycle
Protein degradation

Protein synthesis
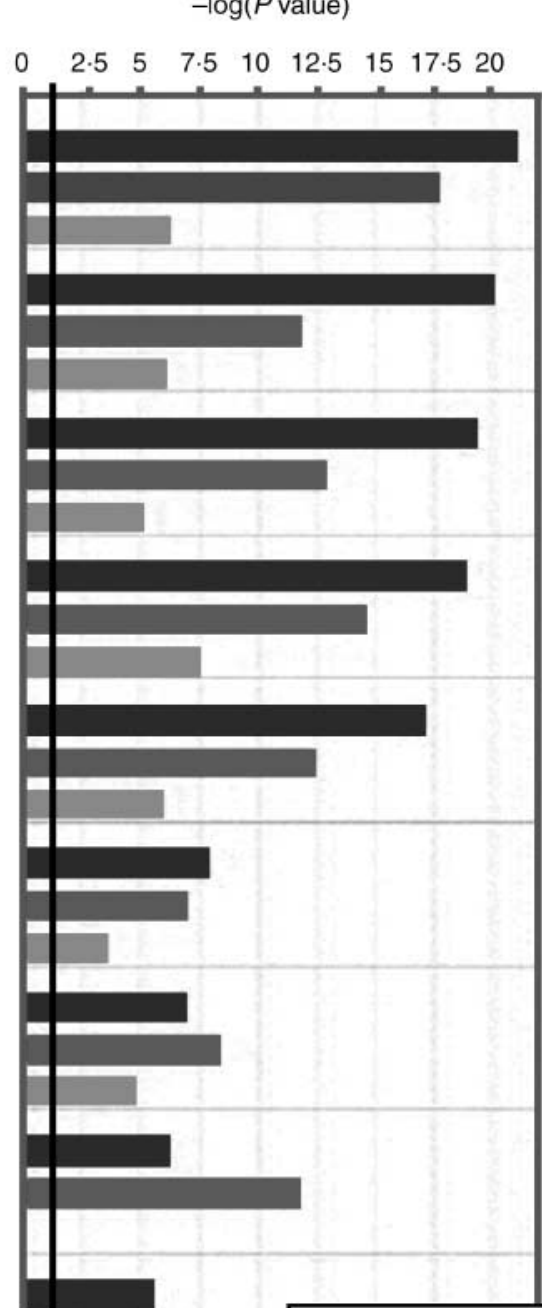

Cellular function and maintenance
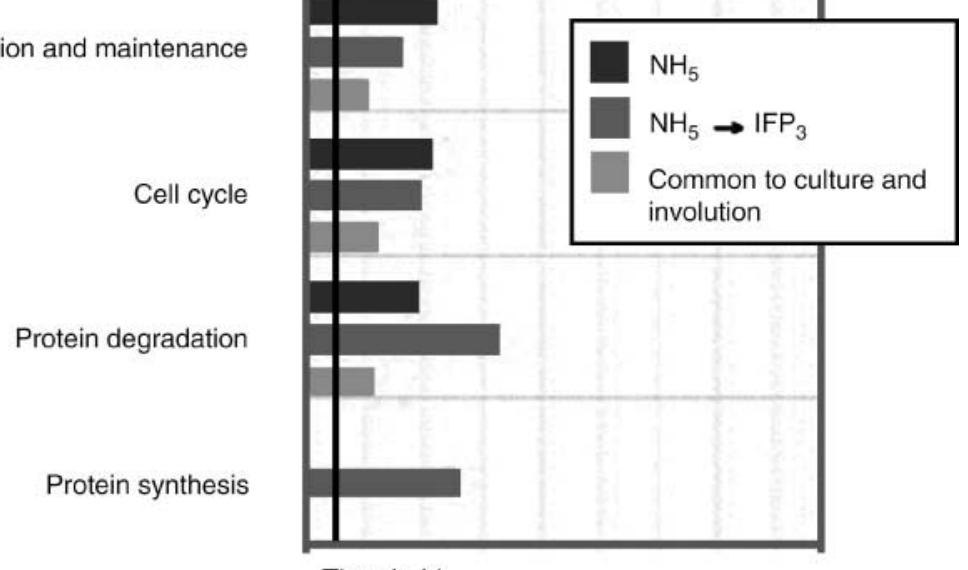

Figure 8 Global functional analysis of cow mammary explant gene expression compared with involution. cDNA probes were hybridised to bovine Affymetrix microarray chips generated from RNA from pregnant cow mammary glands $(n=2)$, explanted mammary tissue from pregnant cows cultured without hormones for 5 days $(n=2)$, explanted mammary tissue from pregnant cows cultured without hormones for 5 days with the subsequent addition of hormones for 3 days $(n=2)$ and involution $(n=4)$. The significance value associated with a function in global analysis is a measure for how likely it is that genes from the dataset file under investigation participate in that function. The significance is expressed as a $P$ value that is calculated using the right-tailed Fisher's exact test. Datasets were integrated and analysed for function using the Ingenuity Pathways Analysis software (Ingenuity ${ }^{\circledR}$ Systems, http://www.ingenuity.com). 
(a)

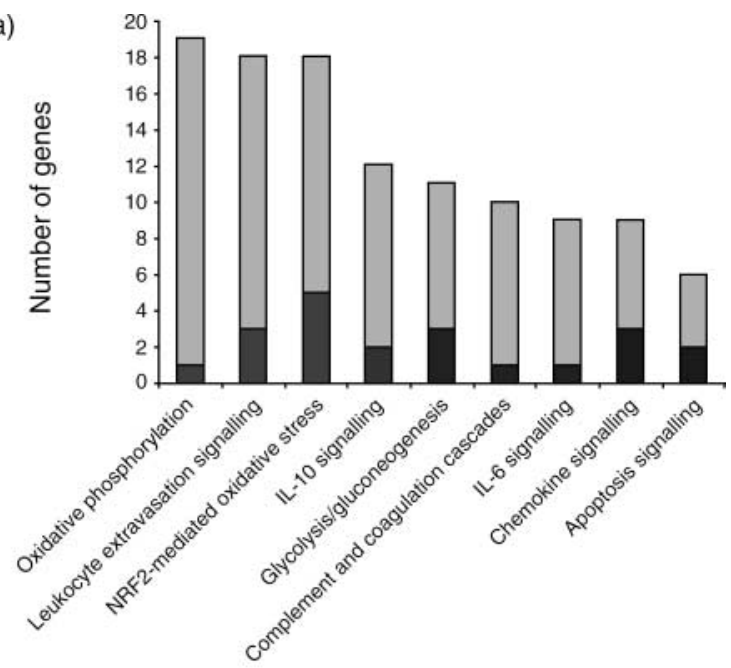

(b)

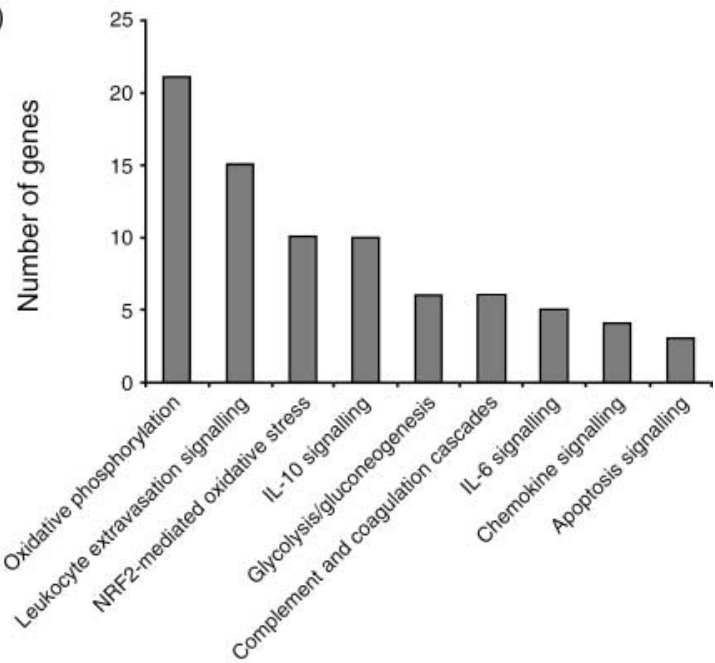

(c)

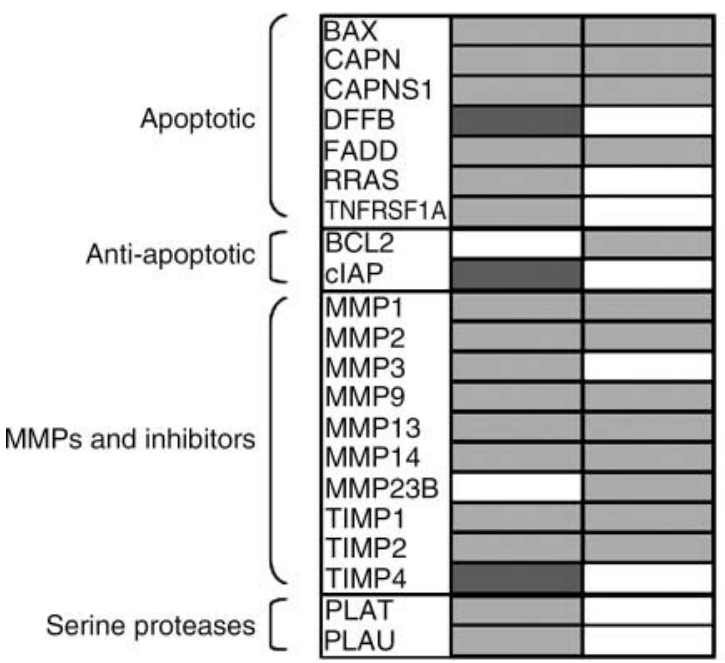

1989). Whether the concomitant up-regulation of proteinase inhibitors such as TIMPs in the nonlactating period is the mechanism that prevents complete mammary gland remodelling in the cow is unclear. However, this may explain the general maintenance of alveoli in mammary explants cultured without hormones, which would be protected from extracellular matrix degradation.

Involution in the rodent is also accompanied by the up-regulation of pro-inflammatory mediators, which include lymphocyte antigens, immunoglobulins and complement components (Clarkson \& Watson 2003, Clarkson et al. 2004). Cow mammary explants also show significantly up-regulated genes in a number of pathways associated with immune responses. Although the role of inflammatory mediators has not been characterised in cow involution, it is thought that an immune infiltrate is recruited to the gland to aid clearance of dying cells (Clarkson \& Watson 2003). The removal of dying epithelial cells by immune cells from explants is unlikely, but whether this affects the survival of explants is unclear. Regardless of the similarities mammary explants have with involuting mammary glands, mammary explants from pregnant dairy cows have a population of surviving cells that remain hormone responsive, are capable of milk protein gene expression and maintain alveolar architecture in the absence of exogenous hormones and growth factors for at least 10 days. These observations are not consistent with the first or second phases of involution, and suggest that mammary epithelial cell survival in the absence of hormones is due to either the lack of a death stimulus, protection by a survival stimulus or a combination of both factors.

Although milk proteins are synthesised and secreted by mammary explants incubated with lactogenic

Figure 9 Comparison of cow mammary explant gene expression in functional biological pathways. cDNA probes were hybridised to bovine Affymetrix microarray chips generated from RNA from pregnant cow mammary glands $(n=2)$, explanted mammary tissue from pregnant cows cultured without hormones for 5 days $(n=2)$ and explanted mammary tissue from pregnant cows cultured without hormones for 5 days with the subsequent addition of hormones for 3 days $(n=2)$. Datasets were integrated and analysed for function using the Ingenuity Pathways Analysis software (Ingenuity ${ }^{\circledR}$ Systems, http://www.ingenuity.com). The significance value associated with a pathway in global analysis is a measure of how likely it is that genes from the dataset file under investigation participate in that function. The significance is expressed as a $P$ value that is calculated using the right-tailed Fisher's exact test. (a) Functional pathways of mammary explants cultured for 5 days without hormones $\left(\mathrm{NH}_{5}\right)$. (b) Functional pathways of mammary explants cultured for 5 days without hormones with the subsequent addition of IFP for 3 days $\left(\mathrm{NH}_{5} \rightarrow\right.$ $\mathrm{IFP}_{3}$ ). (c) Comparison of gene expression from primary apoptosis pathways and extracellular matrix degrading proteins in mammary explants from both treatments $\left(\mathrm{NH}_{5}\right.$ and $\left.\mathrm{NH}_{5} \rightarrow I F P_{3}\right)$. Up-regulated genes are indicated in light grey, and down-regulated genes are indicated in dark grey. 


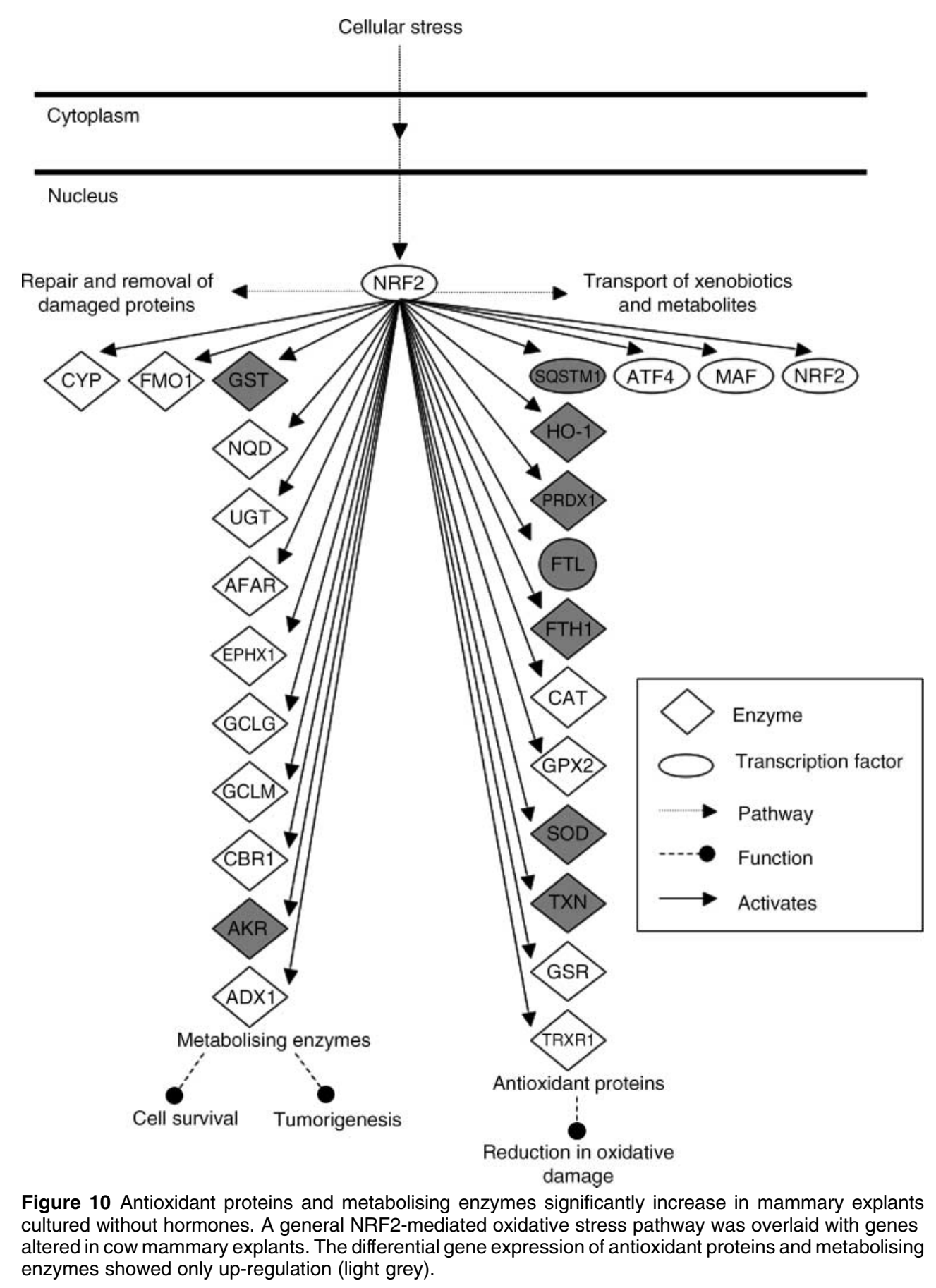

hormones, milk constituents do not accumulate to elevated concentrations such as those at weaning (Nagamatsu \& Oka 1980, Nicholas \& Tyndale-Biscoe 1985). Histology of cow explants also shows that alveoli within explants do not become engorged, which eliminates apoptosis due to stretching of cells or dissociation of tight junctions (Stelwagen et al. 1994, 1997, Singh et al. 2005). Therefore, several death pathways may be avoided in mammary explants, as the accumulation of milk initiates cell death cascades in the first phase of apoptosis (Green \& Streuli 2004). Transgenic mouse studies have been used to identify genes that can inactivate apoptosis pathways in the epithelium. For example, the conditional knockout of mammary-specific signal transducer and activator of transcription (STAT) 3 delays involution because STAT3 
and STAT5 are reciprocally activated in the mammary gland; STAT5 promotes survival and milk secretion, while STAT3 stimulates apoptosis (Chapman et al. 1999, Humphreys et al. 2002). Similarly, microarray analysis of mammary explants showed that members involved in the regulation of the STAT3 pathway were not differentially regulated.

We have shown that the survival of cow mammary explants in culture without hormones is dependent on the synthesis of protein and total RNA. The tissue is not quiescent in the media without hormones, as there is a significant increase in the rate of synthesis of protein and total RNA in explants cultured in the absence of hormones for 5 days. Furthermore, inhibition of this activity results in the loss of hormone-responsive mammary epithelial cells. We found that genes associated with the production of energy are up-regulated in mammary explants, which confirms that mammary cells are active even in the absence of hormones. Inhibition of these genes may prevent mammary explants from providing sufficient energy required for factors that contribute to epithelial cell survival. Furthermore, a number of antioxidant cytoprotective genes that are part of a stress-induced cellular defence mechanism are up-regulated in mammary explants (Long et al. 2002). GSTP1 is a classic detoxification enzyme that has been implicated in resistance to apoptosis initiated by a variety of stimuli, which includes growth factor deprivation (Cumming et al. 2001). TXN is an antioxidant enzyme that also protects cells against apoptosis and can act as a growth factor (Powis \& Montfort 2001). Most of the antioxidant properties of TXN are exerted through thioredoxin peroxidases (PRDXs), which can protect cells from apoptosis induced by serum deprivation (Zhang et al. 1997). Similarly, SOD2 has a critical role in signalling activation, which involves suppression of apoptosis stimulated by a variety of factors (Manna et al. 1998). HMOX1 is believed to exert an anti-apoptotic action by decreasing intracellular pro-oxidant levels (Fang et al. 2004). The cytoprotective nature of these genes may contribute to the survival of a population of mammary epithelial cells in explants. Their induction is most likely due to the stress of culture on the mammary tissue, as both explants cultured without hormones for 5 days and explants cultured for 5 days without hormones with the subsequent addition of hormones for 3 days show an up-regulation of these genes. The identification of these genes may be used as genetic markers for the breeding programmes to improve lactational persistency in dairy cows, as the milk production decline after peak lactation is the result of cell loss by apoptosis.

Previous reports have argued that mammary explants require the addition of serum, insulin or a growth factor to retain tissue viability in culture (Topper \&
Freeman 1980, Kulski et al. 1983, Topper et al. 1984). Although there is a population of apoptotic cells in mammary explants, we have shown that a population of mammary epithelial cells survive without hormones in three evolutionarily distinct species (Brennan et al. 2008). We propose that the mammary explant culture model uncouples the phases of involution, due to the absence of a significant amount of milk accumulation within the secretory alveoli, as milk constituents secreted by mammary explants do not accumulate to elevated concentrations such as those at weaning (Nagamatsu \& Oka 1980, Nicholas \& Tyndale-Biscoe 1985). These observations suggest that mammary epithelial cell survival in the absence of hormones is due to the lack of a death stimulus, protection by a survival stimulus or a combination of both factors. In particular, the identification of genes that may contribute to cell survival in bovine mammary explants may constitute a significant financial advantage for the dairy industry. As the decline in milk yield and quality after peak lactation results in considerable economic loss, the use of novel survival genes as genetic markers for breeding programmes may improve lactational persistency in dairy cows.

\section{Declaration of interest}

The authors declare that there is no conflict of interest that could be perceived as prejudicing the impartiality of the research reported.

\section{Funding}

All funding was provided by the CRC for Innovative Dairy Products.

\section{References}

Accorsi PA, Pacioni B, Pezzi C, Forni M, Flint DJ \& Seren E 2002 Role of prolactin, growth hormone and insulin-like growth factor 1 in mammary gland involution in the dairy cow. Journal of Dairy Science 85 507-513.

Benaud C, Dickson RB \& Thompson EW 1998 Roles of the matrix metalloproteinases in mammary gland development and cancer. Breast Cancer Research and Treatment 50 97-116.

Brennan AJ, Sharp JA, Khalil E, Digby MR, Mailer SL, Lefevre CM \& Nicholas KR 2008 A population of mammary epithelial cells do not require hormones or growth factors to survive. Journal of Endocrinology 196 483-496.

Capuco AV \& Akers RM 1999 Mammary involution in dairy animals. Journal of Mammary Gland Biology and Neoplasia 4 137-144.

Capuco AV, Ellis SE, Hale SA, Long E, Erdman RA, Zhao X \& Paape MJ 2003 Lactation persistency: insights from mammary cell proliferation studies. Journal of Animal Science 81 (Suppl 3) 18-31.

Chapman RS, Lourenco PC, Tonner E, Flint DJ, Selbert S, Takeda K, Akira S, Clarke AR \& Watson CJ 1999 Suppression of epithelial apoptosis and delayed mammary gland involution in mice with a conditional knockout of Stat3. Genes and Development 13 2604-2616. 
Clarkson RW \& Watson CJ 2003 Microarray analysis of the involution switch. Journal of Mammary Gland Biology and Neoplasia 8 309-319.

Clarkson RW, Wayland MT, Lee J, Freeman T \& Watson CJ 2004 Gene expression profiling of mammary gland development reveals putative roles for death receptors and immune mediators in postlactational regression. Breast Cancer Research 6 R92-R109.

Cumming RC, Lightfoot J, Beard K, Youssoufian H, O'Brien PJ \& Buchwald M 2001 Fanconi anemia group C protein prevents apoptosis in hematopoietic cells through redox regulation of GSTP1. Nature Medicine 7 814-820.

Falconer IR, Forsyth IR, Wilson BM \& Dils R 1978 Inhibition by low concentrations of ouabain of prolactin-induced lactogenesis in rabbit mammary gland explants. Biochemical Journal 172 509-516.

Fang J, Akaike T \& Maeda H 2004 Antiapoptotic role of heme oxygenase (HO) and the potential of $\mathrm{HO}$ as a target in anticancer treatment. Apoptosis 9 27-35.

Furth PA 1999 Mammary gland involution and apoptosis of mammary epithelial cells. Journal of Mammary Gland Biology and Neoplasia 4 123-127.

Goldstein JC, Rodier F, Garbe JC, Stampfer MR \& Campisi J 2005 Caspase-independent cytochrome $c$ release is a sensitive measure of low-level apoptosis in cell culture models. Aging Cell 4 217-222.

Green KA \& Streuli CH 2004 Apoptosis regulation in the mammary gland. Cellular and Molecular Life Sciences 61 1867-1883.

Humphreys RC, Bierie B, Zhao L, Raz R, Levy D \& Hennighausen L 2002 Deletion of stat 3 blocks mammary gland involution and extends functional competence of the secretory epithelium in the absence of lactogenic stimuli. Endocrinology 143 3641-3650.

Hurley WL 1989 Symposium: mammary gland function during involution and the declining phase of lactation. Journal of Dairy Science 72 1637-1646.

Irizarry RA, Bolstad BM, Collin F, Cope LM, Hobbs B \& Speed TP 2003 Summaries of Affymetrix GeneChip probe level data. Nucleic Acids Research 31 e15.

Kiernan JA 2000. Histological and Histochemical Methods: Theory and Practice. 3rd edn. Oxford: Butterworth-Heinemann.

Kulski JK \& Hartmann PE 1983 Milk insulin, GH and TSH: relationship to changes in milk lactose, glucose and protein during lactogenesis in women. Endocrinologia Experimentalis 17 317-326.

Kulski JK, Nicholas KR, Topper YJ \& Qasba P 1983 Essentiality of insulin and prolactin for accumulation of rat casein mRNAs. Biochemical and Biophysical Research Communications 116 994-999.

Lee PH, Hwang J, Mead L \& Ip MM 2001 Functional role of matrix metalloproteinases (MMP's) in mammary epithelial cell development. Journal of Cellular Physiology 188 75-88.

Long DJ II, Iskander K, Gaikwad A, Arin M, Roop DR, Knox R, Barrios R \& Jaiswal AK 2002 Disruption of dihydronicotinamide riboside: quinone oxidoreductase 2 (NQO2) leads to myeloid hyperplasia of bone marrow and decreased sensitivity to menadione toxicity. Journal of Biological Chemistry 277 46131-46139.

Manna SK, Zhang HJ, Yan T, Oberley LW \& Aggarwal BB 1998 Overexpression of manganese superoxide dismutase suppresses tumor necrosis factor-induced apoptosis and activation of nuclear transcription factor-kappaB and activated protein-1. Journal of Biological Chemistry 273 13245-13254.

Nagamatsu Y \& Oka T 1980 Purification and characterization of mouse alpha-lactalbumin and preparation of its antibody. Biochemical Journal 185 227-237.

Nicholas KR \& Tyndale-Biscoe CH 1985 Prolactin-dependent accumulation of alpha-lactalbumin in mammary gland explants from the pregnant tammar wallaby (Macropus eugenii). Journal of Endocrinology 106 337-342.

Powis G \& Montfort WR 2001 Properties and biological activities of thioredoxins. Annual Review of Pharmacology and Toxicology 41 261-295.
Quarrie LH, Addey CVP \& Wilde CJ 1996 Programmed cell death during mammary tissue involution induced by weaning, litter removal and milk stasis. Journal of Cellular Physiology 168 559-569.

Rabot A, Sinowatz F, Berisha B, Meyer HH \& Schams D 2007 Expression and localization of extracellular matrix-degrading proteinases and their inhibitors in the bovine mammary gland during development, function, and involution. Journal of Dairy Science 90 740-748.

Recklies AD, White C, Mitchell J \& Poole R 1985 Secretion of a cysteine proteinase from a hormone-independent cell population of cultured explants of murine mammary gland. Cancer Research $\mathbf{4 5}$ 2294-2301.

Rillema JA, Yu TX \& Jhiang SM 2000 Effect of prolactin on sodium iodide symporter expression in mouse mammary gland explants. American Journal of Physiology. Endocrinology and Metabolism 279 E769-E772.

Sheehy PA, Della-Vedova JJ, Nicholas KR \& Wynn PC 2004 Hormonedependent milk protein gene expression in bovine mammary explants from biopsies at different stages of pregnancy. Journal of Dairy Research 71 135-140.

Singh K, Dobson J, Phyn CVC, Davis SR, Farr VC, Molenaar AJ \& Stelwagen K 2005 Milk accumulation decreases expression of genes involved in cell-extracellular matrix communication and is associated with induction of apoptosis in the bovine mammary gland. Livestock Production Science 98 67-78.

Sordillo LM \& Nickerson SC 1988 Morphologic changes in the bovine mammary gland during involution and lactogenesis. American Journal of Veterinary Research 49 1112-1120.

Stefanon B, Colitti M, Gabai G, Knight CH \& Wilde CJ 2002 Mammary apoptosis and lactation persistency in dairy animals. Journal of Dairy Research 69 37-52.

Stein T, Morris JS, Davies CR, Weber-Hall SJ, Duffy MA, Heath VJ, Bell AK, Ferrier RK, Sandilands GP \& Gusterson BA 2004 Involution of the mouse mammary gland is associated with an immune cascade and an acute-phase response, involving LBP, CD14 and STAT3. Breast Cancer Research 6 R75-R91.

Stelwagen K, Davis SR, Farr VC, Prosser CG \& Sherlock RA 1994 Mammary epithelial cell tight junction integrity and mammary blood flow during an extended milking interval in goats. Journal of Dairy Science 77 426-432.

Stelwagen K, Farr VC, McFadden HA, Prosser CG \& Davis SR 1997 Time course of milk accumulation-induced opening of mammary tight junctions, and blood clearance of milk components. American Journal of Physiology 273 R379-R386.

Tatarczuch L, Philip C \& Lee CS 1997 Involution of the sheep mammary gland. Journal of Anatomy 190 405-416.

Topper YJ \& Freeman CS 1980 Multiple hormone interactions in the developmental biology of the mammary gland. Physiological Reviews 60 1049-1106.

Topper YJ, Nicholas KR, Sankaran L \& Kulski JK 1984 Insulin biology from the perspective of studies on mammary gland development. In Biochemical Actions of Hormones, pp 163-186. Ed G Litwack. New York: Academic Press.

Zhang P, Liu B, Kang SW, Seo MS, Rhee SG \& Obeid LM 1997 Thioredoxin peroxidase is a novel inhibitor of apoptosis with a mechanism distinct from that of Bcl-2. Journal of Biological Chemistry 272 30615-30618.

Received in final form 19 May 2008

Accepted 5 June 2008

Made available online as an Accepted Preprint 5 June 2008 